\title{
Inhibition of phosphoinositide 3-kinase impairs pre- commitment cell cycle traverse and prevents differentiation in erythroleukaemia cells
}

\author{
A Bavelloni ${ }^{2}$, I Faenza ${ }^{3}$, M Aluigi ${ }^{2}$, A Ferri $^{4}$, A Toker $^{5}$, \\ NM Maraldi ${ }^{1,2}$ and S Marmiroli ${ }^{*, 1}$ \\ 1 Institute of Cytomorphology C.N.R., Bologna, Italy \\ ${ }^{2}$ Cell Biology Laboratory I.O.R., Bologna, Italy \\ ${ }^{3}$ Cellular Signalling Laboratory, Institute of Anatomy, University of Bologna, Italy \\ ${ }^{4}$ Department of Biochemistry, University of Ferrara, Italy \\ ${ }^{5}$ Signal Transduction Group, Boston Biomedical Research Institute, Boston, \\ Massachusetts 02114, USA. \\ * Corresponding author: Sandra Marmiroli, Istituto di Citomorfologia Normale e \\ Patologica del C.N.R., via di Barbiano 1/10, 40136 Bologna, Italy. \\ Tel: 39-51-6366770; Fax: 39-51-583593; E-mail: marmiroli@area.bo.cnr.it
}

Received 4.5.99; revised 31.7.99; accepted 6.9.99 Edited by TG Cotter

\begin{abstract}
During the early hours after exposure to differentiation inducing agents, Friend erythroleukaemia cells undergo alterations which commit them to cessation of growth and development of the characteristics of differentiation. Our current experiments have compared the expression and activity of phosphoinositide 3-kinase (PI 3-kinase) in control cells with cells undergoing differentiation which has been induced by dimethyl sulfoxide (DMSO). When the cultures were initiated with stationary phase cells and DMSO was added at the time of seeding, PI 3-kinase activity was stimulated in both treated and control cells during the first $3 \mathrm{~h}$ from seeding. This event appears to be a rate limiting step in commitment since pretreatment of cells with $10 \mu \mathrm{M}$ LY294002 or down-regulation of p85 expression prior to adding DMSO completely prevents commitment to erythropoiesis. Accordingly, PI 3-kinase inhibition during the commitment period prevents DNA-binding of the transcription factor GATA-1, essential for erythroid differentiation. However, once cells are committed to differentiate, PI 3-kinase activity and expression dramatically decreases along with the differentiation programme, to become barely detectable after $96 \mathrm{~h}$. Remarkably, LY294002 treatment leads to accumulation of cell in G1 phase and prevents DMSO-dependent cyclin D3 induction. Based on these data, we suggest that PI3-kinase is rate limiting for the completion of the first round cycle of cell division required for initiation of erythrocytic differentiation. On the other hand, the late decrease of PI 3-kinase associated with the differentiation process seems to be part of the programmed shut off of genes not needed in mature erythrocytes. Cell Death and Differentiation (2000) 7, 112-117.
\end{abstract}

Keywords: PI3-kinase; differentiation; cell cycle; cyclin-D3; GATA.

Abbreviations: PI, 3-kinase; phosphoinositide 3-kinase; DMSO, dimethyl sulfoxide; HMBA, hexamethylenbisacetamide; w, wortmannin

\section{Introduction}

Murine erythroleukaemia cells are derived from erythroleukaemia by infection of Friend spleen-focus forming virus, causing Epo-independent polyclonal expansion through constitutive activation of the EpoR. ${ }^{1}$

During the early hours after exposure to differentiation inducing agents, such as the hybrid polar compounds dimethyl sulfoxide (DMSO) or hexamethylenebisacetamide $(\mathrm{HMBA})$, Friend cells undergo alterations which commit them to cessation of growth and development of the characteristics of differentiation. ${ }^{1}$ The commitment phase is a latent period $(10-12 \mathrm{~h})$ during which a number of events take place: among the inducer-mediated changes, transient prolongation of G1 phase has been observed, characterized by accumulation of underphosphorylated $\mathrm{pRb}$ and cyclin D3, while cyclin A and cdk2 decrease. ${ }^{2}$ Induction of differentiation in Friend cells is a cell cycle dependent event, and the completion of the first round cycle of cell division is required for initiation of erythrocytic differentiation. $^{3}$ However, little is known about the early signals generated by the inducers.

Phosphoinosite 3-kinases (PI 3-kinase) are recruited and activated by a number of growth factor receptor systems, and play essential roles in both proliferative and nonproliferative cellular functions. ${ }^{4,5}$ All $\mathrm{PI}$ 3-kinase isoforms so far described are inhibited in the nanomolar or low micromolar range by two structurally unrelated membrane permeant inhibitors, wortmannin (W) and LY294002. ${ }^{6}$

While a large body of data has been accumulating on the role of $\mathrm{PI} 3$-kinase in tyrosine kinase receptor transduction or vesicle trafficking, little is known about the possible role of $\mathrm{PI}$ 3-kinase in cell differentiation. In this regard, it has been observed that $\mathrm{PI}$ 3-kinase might be involved in neurite outgrowth of PC12 cells, ${ }^{7}$ in differentiation of skeletal muscle cells ${ }^{8,9}$ and, more recently, in ATRAinduced differentiation of $\mathrm{HL} 60$ cells. ${ }^{10}$

Here we show that treatment of Friend cells with the PI 3-kinase inhibitors wortmannin or LY294002 during the commitment phase or expression of a dominant negative p85 completely blocks biochemical changes associated with terminal differentiation. Our data hint at a key role for PI 3-kinase in the G1 to S-phase transition, essential for the completion of the first round cycle of cell division required for commitment to erythroid differentiation. 


\section{Results}

Our current experiments have compared the expression and activity of PI 3-kinase in control cells with cells undergoing erythroid differentiation which has been induced by DMSO or HMBA. When cultures were initiated with stationary phase cells, PI 3-kinase activity was stimulated by about tenfold both in DMSO-treated and control cells, during the first $3 \mathrm{~h}$ from seeding (Figure 1a). In uninduced cells the activity then declines slowly back to basal level, to remain steady throughout the remaining 4 days. Conversely, in DMSOinduced cells both the activity (Figure 1a) and the expression of PI 3-kinase significantly decrease along with the differentiation program, to be barely detectable after $96 \mathrm{~h}$ (Figure 1b,c). However in the presence of the PI 3-kinase inhibitor LY294002 during the commitment period, p85 expression is only slightly reduced after $96 \mathrm{~h}$ of DMSOinduction, as shown in Figure 1d. LY294002 is a potent inhibitor of $\mathrm{PI} 3$-kinase, with an $\mathrm{IC}_{50}$ in the micromolar range, ${ }^{6}$ and it binds to the $110 \mathrm{kDa}$ catalytic subunit of PI 3-kinase. Remarkably, quiescent Friend cells diluted into fresh medium containing $10 \mu \mathrm{M}$ LY294002 for $10 \mathrm{~h}$ during the commitment period showed a dramatic inhibition of DMSO-induced terminal differentiation, as measured by hemoglobin levels (Figure 2a). These cells, in which PI 3-kinase expression was not down-modulated, are therefore resistant to differentiation.

Induction of differentiation in Friend cells is a cell cycle dependent event, and the completion of the first round cycle of cell division is a prerequisite for initiation of erythrocytic differentiation. ${ }^{1,3}$ To assess the potential physiologic role of $\mathrm{PI}$ 3-kinase in Friend cells differentiation we determined the effect of $\mathrm{Pl}$ 3-kinase specific inhibitors on cell cycle progression. Quiescent Friend cells represent a relatively homogeneous cell population to study red cell maturation. Cells were released from $\mathrm{G} 1$ phase by dilution in fresh medium with $10 \%$ serum, and assessed for cell cycle progression by flow cytometry. Figure $2 b$ shows the effect of LY294002 on the distribution of cells throughout the cell cycle. At stationary phase, $80 \%$ of the cell population was in the $\mathrm{G} 1 / \mathrm{G} 0$ phase of the cell cycle. After dilution into fresh medium, 16-18 $\mathrm{h}$ were required for the cell population to attain a stable distribution with respect to the cell cycle. FACS analysis of propidium iodide stained nuclei showed that a subpopulation (70\%) of the cells had entered S-phase by that time (Figure 2a). At the moment that LY294002 was added to the culture this subpopulation was still in $\mathrm{G} 1$ phase. Treatment with $10 \mu \mathrm{M}$ LY294002 more than halved the percentage of cell entry into S-phase. The presence of $10 \mu \mathrm{M}$ LY294002 at that time in the culture medium blocked the ability of the cells to progress through $\mathrm{G} 1$ phase in response to serum, suggesting that PI 3-kinase activity is rate limiting for the completion of the first round cycle of cell division. Treatment of cells with wortmannin, a potent inhibitor of PI 3kinase structurally unrelated to LY294002, yielded the same effects (not shown). These results prompted us to investigate the effect of PI 3-kinase inhibitors on the early events which characterize erythrocytic differentiation.

GATA-1 is a zinc finger DNA-binding protein involved in the expression of numerous erythroid specific genes. ${ }^{11,12}$ The promoters and enhancers of globin genes contain target sites for GATA-1. Figure 3 shows the effect of wortmannin and LY294002 on GATA-1 DNA binding in cells induced to differentiation. As expected, in cells treated for $18 \mathrm{~h}$ with DMSO or HMBA GATA-1 binding to DNA was clearly detectable. However, no retarded complex was

A

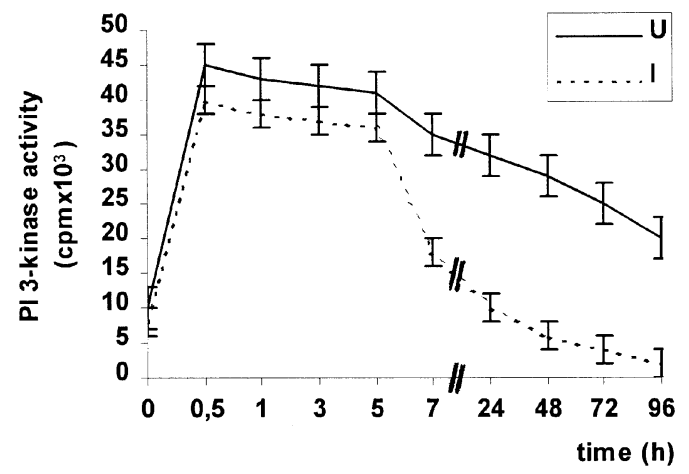

B

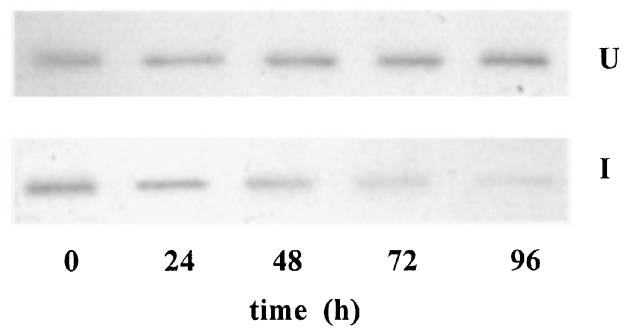

C

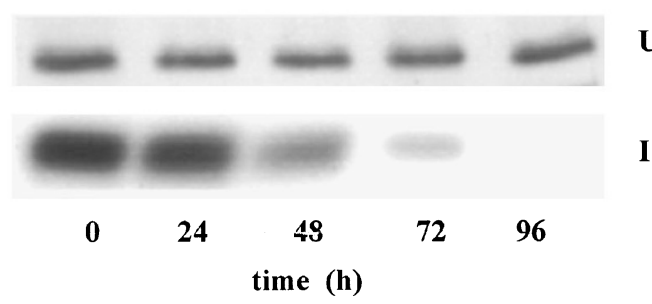

$\mathbf{U}$

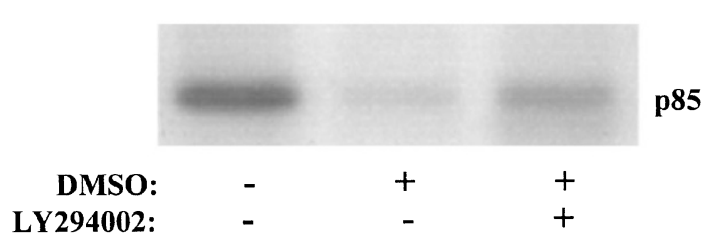

Figure 1 PI 3-kinase modulation during Friend cells differentiation Quiescent cells were diluted at $2 \times 10^{5}$ with fresh medium containing $10 \%$ FCS. (a) At different time-points cells were harvested and assayed for PI 3 kinase activity. (b) Cells were grown for 4 days in the presence (I) or in the absence $(\mathrm{U})$ of $1.5 \% \mathrm{DMSO}$ and aliquots were collected every day for Western blot analysis (anti-p85 1:3000, UBI) (b) or Northern blot (c) of p85. Panel d shows the effect of LY294002 on p85 expression (Northern blot) after 4 days of induction without or with DMSO 
visible in cells pretreated with wortmannin or LY294002, suggesting that PI 3-kinase is indeed essential during the early events which characterize the commitment phase.

Although wortmannin and LY294002 are considered to be a rather selective inhibitors of $\mathrm{PI}$ 3-kinase, and most of their cellular effects are thought to be the result of this inhibition, there is evidence that, at high doses, they may inhibit other enzymes. ${ }^{6}$ The role of PI 3-kinase in DMSOinduced differentiation was therefore investigated blocking the expression of the regulatory subunit p85 by antisense cloning in a retroviral vector. Forty eight hours postinfection, cells were treated with DMSO to induce terminal differentiation. In agreement with previous results the downregulation of p85, shown in Figure $4 \mathrm{a}$, largely decreases the expression of beta-globin and therefore prevents Friend cells from terminal differentiation (Figure 4b).

The effect of PI 3-kinase could be due to inactivation of an early transduction mechanism necessary for progression in mid to late G1. One of the known downstream events of PI 3kinase is activation of Akt/PKB and p70S6-kinase. ${ }^{13} \mathrm{We}$ therefore investigated the fluctuation of Akt and p70S6kinase activity during the first hour after induction. When quiescent Friend cells were diluted in fresh medium with serum, a significant increase of Akt/PKB Ser 473 phosphor-

A

\begin{tabular}{lr}
\hline \multicolumn{1}{c}{ Treatment } & \% Differentiation \\
\hline & \\
control & $0 \pm 2$ \\
DMSO & $75 \pm 6$ \\
LY294002 & $2 \pm 1$ \\
DMSO + LY294002 & $25 \pm 3$ \\
\hline
\end{tabular}

\section{B}

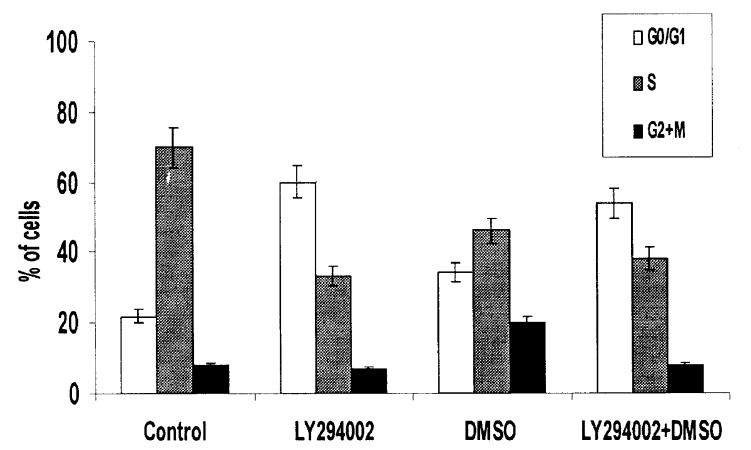

Figure 2 Effect of DMSO and LY294002 on Friend cells differentiation. (a) The degree of cell differentiation after $96 \mathrm{~h}$ induction with $1.5 \%$ DMSO was determined by measuring the percentage of benzidine-staining positive cells. Benzidine staining was performed by adding $10 \mu \mathrm{l}$ of freshly prepared benzidine solution containing $0.6 \% \mathrm{H}_{2} \mathrm{O}_{2}, 0.5 \mathrm{M}$ acetic acid and $0.2 \%$ benzidine dihydrochloride (Sigma) to $50 \mu$ l of cells. Positive cells (blue cells) were counted in a hemocytometer by light microscopy. (b) Quiescent Friend cells were diluted at $2 \times 10^{5}$ with fresh medium containing $10 \%$ FCS for $16 \mathrm{~h}$ then flow cytometric analysis of propidium iodide stained nuclei was performed. Cells were treated with $10 \mu \mathrm{M} \mathrm{LY} 294002$, alone or in combination with DMSO, where indicated

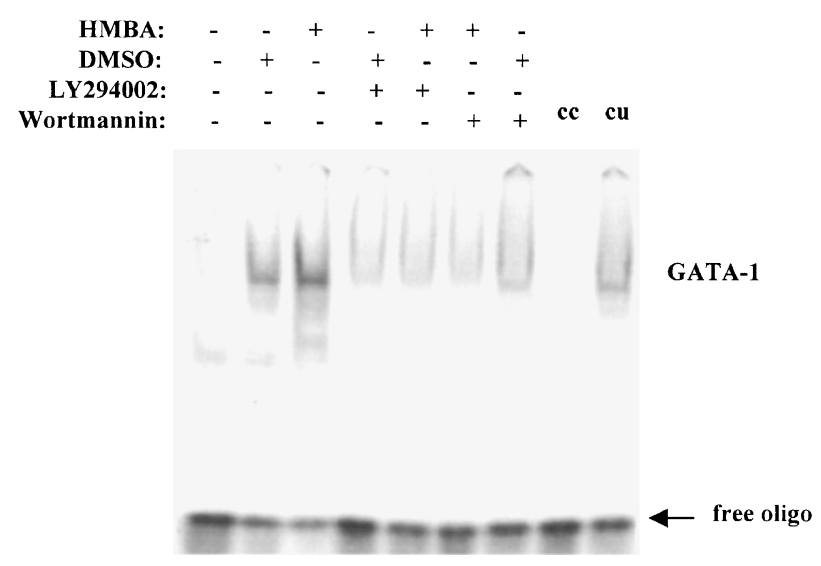

Figure 3 Effect of LY294002 or wortmannin on GATA-1 binding to DNA. Ten $\mu \mathrm{g}$ of nuclear protein from Friend cells uninduced or induced for $18 \mathrm{~h}$ with DMSO or HMBA were incubated with a ${ }^{32} \mathrm{P}$-labelled double strand synthetic oligonucleotide reproducing the GATA-1 DNA binding site to analyze the formation of a specific GATA-1-DNA complex by mobility shift assay. cc: preincubation with cold GATA-1 oligo; cu: preincubation with cold uncompetitor. Where indicated, cells were treated with $10 \mu \mathrm{M}$ LY294002 for $10 \mathrm{~h}$ during the commitment period

$\mathbf{A}$

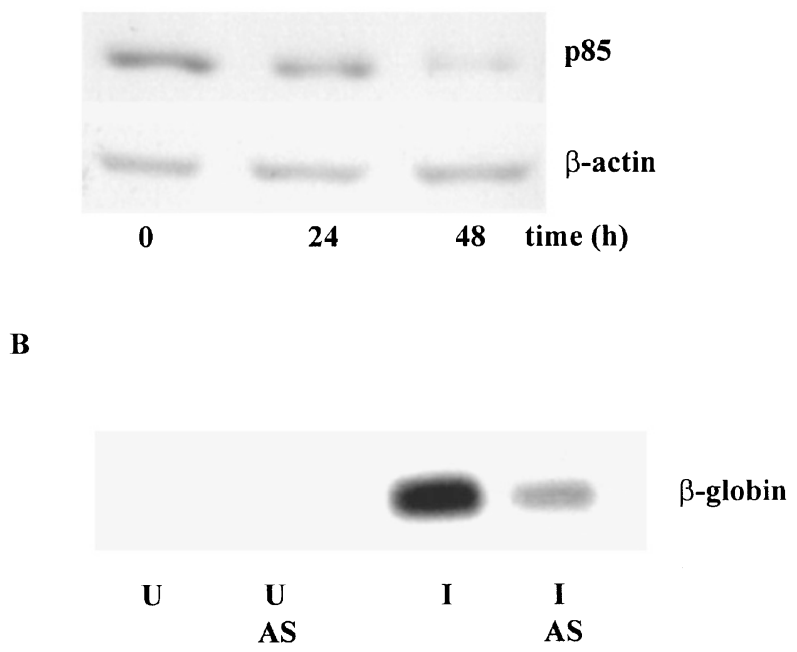

Figure 4 DMSO-induced p85-deficient Friend cells express low levels of $\beta$ globin. Friend cells transiently infected with a retrovirus containing antisense p85; cells were analyzed for p85 expression by Western blotting 24 and $48 \mathrm{~h}$ post-infection (a). Then cells were differentiated for 4 days in the presence of $1.5 \%$ DMSO (I) or not (U), and analyzed for $\beta$-globin expression by Northern blotting (b)

ylation was observed (Figure 5a). Concomitantly, p70S6kinase activity increased by about tenfold (Figure 5b). As expected, these responses were completely inhibited by LY294002. Remarkably, in cells induced with HMBA for $18 \mathrm{~h}$ in the presence of the S6-kinase inhibitor rapamycin, GATA-1 binding to DNA is markedly reduced (Figure 6). This result suggests that the function of PI 3-kinase in Friend cells differentiation is mediated through the downstream $\mathrm{PI} 3-$ kinase dependent Akt/p70 S6-kinase pathway.

As mentioned before, HMBA-induced differentiation has been shown to be associated with striking changes in the pattern of expression of cyclins and cdks. In particular, in 
Friend cells HMBA induces the expression of cyclin D3, which in turn forms complexes with $\mathrm{pRB}$ and E2F. ${ }^{14}$ It has recently been reported that cyclin $D$ expression is controlled post-transcriptionally via a PI 3-kinase/Aktdependent pathway. ${ }^{17-19}$ We therefore examined whether $\mathrm{PI}$ 3-kinase is required for HMBA-induced expression of

A

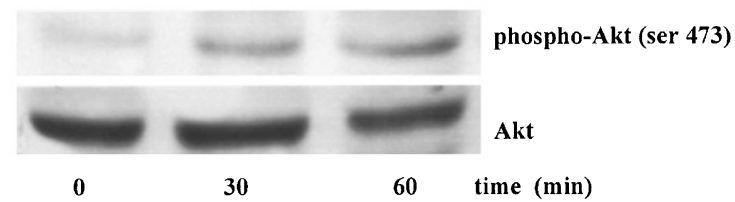

B

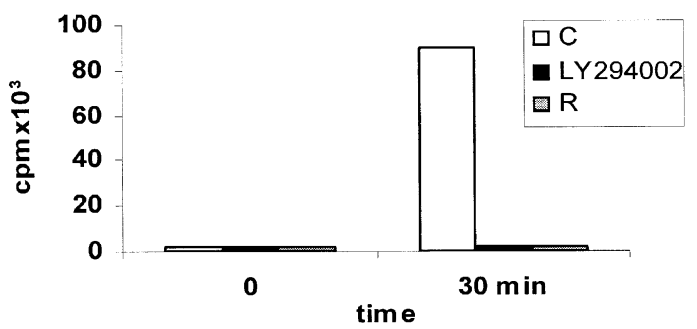

Figure 5 Activation of Akt and p70S6-kinase in response to serum. Quiescent Friend cells were diluted at $2 \times 10^{5}$ with fresh medium containing $10 \%$ FCS for $30 \mathrm{~min}$. (a) Akt activity was determined by Western blotting using anti-Akt or anti-phospho-Akt (Ser 473) antibodies (1:800, NEB). (b) One hundred $\mu \mathrm{g}$ of cleared lysates were immunoprecipitated with $5 \mu \mathrm{l}$ anti S6kinase then kinase activity was determined by phosphorylation of a specific peptide. Where indicated, cells were pretreated for $15 \mathrm{~min}$ with LY294002 or rapamycin $(R)$

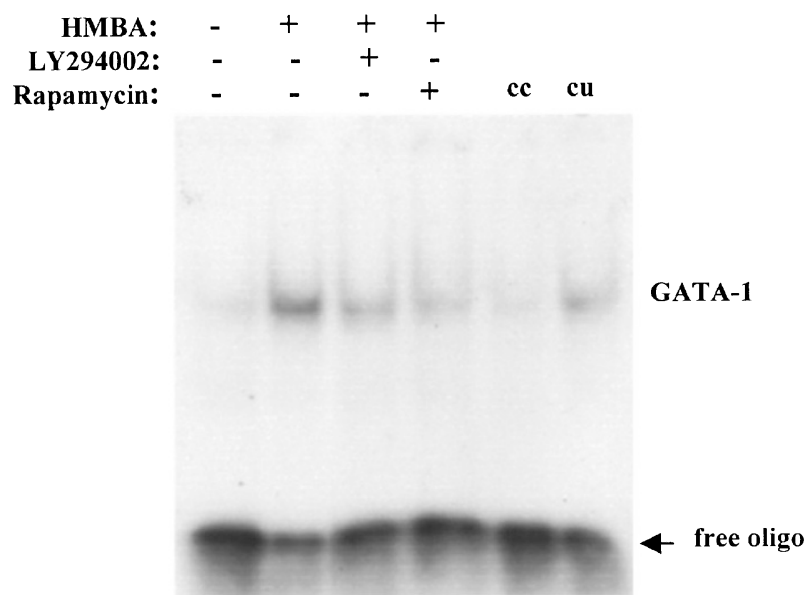

Figure 6 Effect of rapamycin on GATA-1 binding to DNA. Quiescent cells were diluted at $2 \times 10^{5}$ with fresh medium containing $10 \%$ FCS in the presence of either $100 \mathrm{nM}$ rapamycin, $5 \mathrm{mM} \mathrm{HMBA}$ or a combination of the two for $18 \mathrm{~h}$. Ten $\mu \mathrm{g}$ of nuclear protein were incubated with a ${ }^{32} \mathrm{P}$-labelled double strand synthetic oligonucleotide reproducing the GATA-1 DNA binding site to analyze the formation of a specific GATA-1-DNA complex by mobility shift assay. cc: preincubation with cold GATA-1 oligo; cu: preincubation with cold uncompetitor

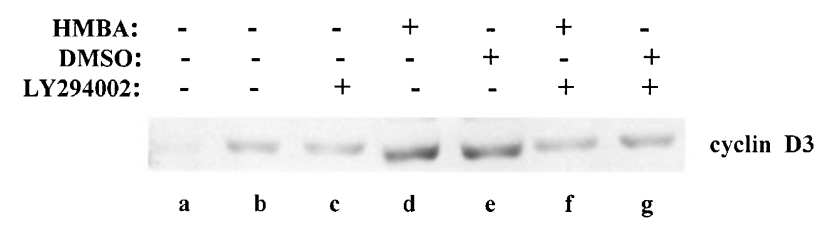

Figure 7 PI 3-kinase inhibiton down-regulates HMBA-induced cyclin D3 expression. Quiescent cells were diluted in fresh medium containing 10\% FCS for $18 \mathrm{~h}$, then $10 \mu \mathrm{g}$ of cleared cell lysates were loaded on $12 \%$ SDS-PAGE, transferred onto nitrocellulose filter and probed with anti-cyclin D3 polyclonal antibody ( $1: 750$, Santa Cruz). Lanes a: quiescent cells; lanes b-g: cells diluted for $1 \mathrm{~h}$ in fresh medium containing $1.5 \% \operatorname{DMSO}(\mathrm{e}, \mathrm{g})$ or $5 \mathrm{mM} \mathrm{HMBA}(\mathrm{d}, \mathrm{f})$ and $10 \mu \mathrm{M}$ LY294002 (c,f,g)

cyclin D3 protein. After treatment with HMBA or DMSO for $18 \mathrm{~h}$, cyclin D3 was detected by immunoblotting. The presence of LY294002 in the incubation medium during the commitment period markedly suppressed the induction of cyclin D3 in response to HMBA or DMSO (Figure 7). These findings agree with the results described above and indicate that PI 3-kinase is critically required for upregulation of cyclin D3 protein in response to the inducers.

\section{Discussion}

Erythroid differentiation is a complex and finely tuned multistep process, resulting in cessation of cell division and phenotypic maturation (including hemoglobin production). Hybrid polar compounds, such as HMBA and DMSO, are potent inducers of differentiation of Friend erythroleukaemia cells and a variety of other transformed cells, although these inducers are not adequate therapeutic agents because of their dose-limiting toxicity. ${ }^{1}$ During the early hours after exposure to differentiation inducing agents, Friend erythroleukaemia cells undergo modifications which commit them to cessation of growth and development of the characteristics of differentiation. Differentiation of Friend cells is a cell cycle-dependent event, in which al least one round cycle must be completed for the cells to become committed to differentiate. ${ }^{2,3}$

It is known that the inducers alter the G1 to S-phase transition, leading to $\mathrm{G} 1$ arrest and inhibition of DNA synthesis. Among the inducer-mediated changes, increase p21 levels and suppression of Cyclin-dependent kinase cdk4 have been documented, ${ }^{14-16}$ leading to underphosphorylation of $\mathrm{pRB}$ and $\mathrm{G} 1$ prolongation.

In this work we have compared the expression and activity of PI 3-kinase in control cells with cells undergoing differentiation which has been induced by DMSO or HMBA. When the cultures were initiated with quiescent cells and DMSO was added at the time of seeding, PI 3-kinase activity was stimulated in both treated and control cells during the early hours of the commitment period. Thereafter, both activity and expression stabilized rapidly back to basal level in uninduced cells but decrease dramatically in induced cells, to be almost undetectable 4 days after the induction. Concomitantly, blocking PI 3-kinase activity with the inhibitor LY294002 during the commitment phase prevented cells from entering S-phase. This event appears to be a rate limiting step in commitment, since in the presence of LY294002 DMSO-induced terminal differentiation was inhibited (as measured by hemoglobin production). 
Remarkably, in these cells PI 3-kinase expression was not down-regulated by the presence of DMSO. Furthermore, we demonstrated that the binding of the transcription factor GATA-1 to its site, a pre-requisite in erythroid differentiation, ${ }^{11,12}$ is modulated by $\mathrm{PI}$ 3-kinase, as wortmannin and LY294002 abolish almost completely DMSO-induced or HMBA-induced GATA-1 binding to DNA. Furthermore, another event crucial to erythroid differentiation, namely HMBA-induced up-regulation of cyclin $D 3,{ }^{15}$ is also completely prevented by LY294002, suggesting a direct implication of the PI 3-kinase/Akt-dependent pathway in this process. In conclusion, blocking either the activity with specific inhibitors or the expression by antisense cloning, we were able to demonstrate that PI 3-kinase is necessary for the G1-S-transition in Friend cells, in agreement with previous indications of the role of PI 3-kinase on cell cycle progression. ${ }^{17}$ On the other hand, it should be noted that if the inhibitor is removed prior to the end of the commitment phase cells recover the ability to re-enter the cell cycle, suggesting that functional PI 3-kinase is necessary in mid to late G1 phase. It is to be reminded that several studies have already shown that the cell lipid content can influence the cell cycle. ${ }^{20,21}$ Furthermore, it has recently been demonstrated that overexpression of a specific, nuclear localized, phosphoinositidase $\mathrm{C} \beta 1$ isoform is sufficient to maintain the undifferentiated state of Friend cells induced with DMSO. ${ }^{22,23}$ Therefore, PI 3-kinase is being increasingly regarded as one of the key signaling molecules in G1to S-progression. Previous work done by Roche et al ${ }^{24}$ showed that $\mathrm{PI}$ 3-kinase is required during the G1-to-Sphase transition for DNA synthesis induced by some growth factors. Moreover, a recent report by Klippel et al ${ }^{17}$ demonstrates that selective activation of $\mathrm{PI}$ 3-kinase is sufficient for cell cycle entry and DNA onset, though completion of S-phase requires other pathways. According to this work, PI 3-kinase promotes the entry of quiescent cells into the cell cycle by activating $\mathrm{G} 1$ and G1/S-phase cyclin-Cdk complexes, ${ }^{17}$ and this has been confirmed by recent reports showing that cyclin $D$ expression is regulated via a PI 3-kinase/Akt-dependent pathway, ${ }^{18,19}$ in agreement with the data reported here.

The set up of a differentiated erythroid phenotype requires a number of molecular intermediates, such as cyclins and cdks, transcription factors, such as GATA-1, and signaling molecules which collectively accomplish the programmed phenotypic change involving restricted replication and transcription of erythroid-specific genes. The data presented here clearly demonstrate that PI 3-kinase is an essential component of this mechanism (as suppression of PI 3-kinase completely abolishes terminal differentiation of Friend cells), being rate limiting for the completion of the first round cycle of cell division required for initiation of erythrocytic differentiation.

\section{Materials and Methods}

\section{Antibodies and reagents}

All culture reagents were purchased from GIBCO, while radioisotopes, secondary antibodies and enhanced chemiluminiscence (ECL) reagents from Amersham; wortmannin and LY294002 were from
Alexis and anti p85 polyclonal antibody and p70 S6-kinase substrate peptide were from UBI. Anti p70 S6 kinase, anti-cyclin D3 were from Santa Cruz, anti-phospho p70 S6K and anti-phospho Akt were from New England Biochemicals.

\section{Cells and cultures}

Murine erythroleukaemia cells (Friend cells, clone 707) were grown in RPMI 1640 supplemented with 10\% foetal calf serum (FCS) and diluted at $2 \times 10^{5} / \mathrm{ml}$ every 2 days. Erythroid differentiation was induced by addition of $1.5 \%$ (v/v) Dimethylsulfoxyde (DMSO) or $5 \mathrm{mM}$ Hexamethylenebisacetamide (HMBA) to the culture medium for 4 days. When needed, $100 \mathrm{nM}$ wortmannin, $100 \mathrm{nM}$ rapamycin or $10 \mu \mathrm{M}$ LY 294002 were added to the dilution medium for $10 \mathrm{~h}$ during the commitment period. Vehicle DMSO $0.001 \%$ was added to control cells.

\section{In vitro kinase activity and Western blotting}

Cells were lysed in a lysis buffer composed of $0.1 \%$ NP-40, $20 \mathrm{mM}$ Tris- $\mathrm{HCl}(\mathrm{pH} 7.5) 150 \mathrm{mM} \mathrm{NaCl}, 0.1 \mathrm{mM}$ EDTA, $100 \mu \mathrm{M}$ sodium orthovanadate, $10 \mathrm{mM}$ p-nitrophenyl phosphate, $100 \mathrm{nM}$ microcystin, $1 \mathrm{mM}$ PMSF, $10 \mu \mathrm{g} / \mathrm{ml}$ aprotinin and leupeptin on ice. After clarification by spinning at 15000 r.p.m. for $20 \mathrm{~min}$ in a refrigerated microcentrifuge, $1 \mathrm{mg}$ of lysate was subjected to immunoprecipitation with $2 \mu \mathrm{g}$ of anti-p85 for $2 \mathrm{~h}$ at $4^{\circ} \mathrm{C}$ in IP buffer $(20 \mathrm{mM}$ Hepes, $\mathrm{pH} 7.4,1 \% \mathrm{NP}$ $40,10 \%$ glycerol, $50 \mathrm{mM} \mathrm{NaF}, 100 \mathrm{mM} \mathrm{NaCl}, 100 \mathrm{mM}$ sodium orthovanadate, $10 \mathrm{mM}$ p-nitrophenyl phosphate, $100 \mathrm{nM}$ microcystin, $1 \mathrm{mM}$ PMSF, $10 \mu \mathrm{g} / \mathrm{ml}$ aprotinin and leupeptin), followed by $1 \mathrm{~h}$ incubation with $50 \mu \mathrm{l}$ of protein A (10\%). For immunoblot analysis, pellets were heated for $5 \mathrm{~min}$ at $100^{\circ} \mathrm{C}$ in Laemmli's SDS sample buffer, run on a 7.5\% SDS-PAGE and electrotransferred to nitrocellulose (BIO RAD). The membranes were probed with antip85 (UBI, 1:3000), anti-Akt or anti-phospho-Akt (Ser 473, 1:1000, NEB) for one hour at room temperature, followed by detection using ECL. For PI 3-kinase activity, pellets were treated as described previously. ${ }^{25}$ p70 S6 kinase was assayed against a specific peptide (UBI), and incubation was stopped with $7 \%$ trichloroacetic acid. Supernatants were spotted onto Whatman P-81 phosphocellulose, and filters were washed four times in cold $75 \mathrm{mM}$ phosphoric acid, rinsed with acetone and counted in a beta-counter.

\section{Cell cycle analysis}

Cells were harvested, washed in cold PBS, fixed in ice-cold $70 \%$ ethanol and stored at $-20^{\circ} \mathrm{C}$ until use. Pellets were resuspended in PBS containing Bovine Pancreas Ribonuclease (Sigma) at a final conc of $1.3 \mathrm{mg} / \mathrm{ml}$ and RNA digestion was carried out for $15 \mathrm{~min}$ at $37^{\circ} \mathrm{C}$. The DNA was stained with propidium iodide $(50 \mathrm{mg} / \mathrm{ml})$. Flow cytometric analysis of stained nuclei was performed in a FACS star plus (Becton Dickinson). Propidium iodide fluorescence was excited at $488 \mathrm{~nm}$ by argon laser.

\section{Preparation of nuclear extracts and gel shift assay (EMSA)}

For preparation of nuclear extracts, cells were swelled in buffer $\mathrm{A}$ (10 mM Hepes pH 7.9, $1.5 \mathrm{mM} \mathrm{MgCl}, 10 \mathrm{mM} \mathrm{KCl}, 0.5 \mathrm{mM}$ DTT, $0.5 \mathrm{mM}$ PMSF) for $10 \mathrm{~min}$ at $4^{\circ} \mathrm{C}$ and lysed by vortexing $15 \mathrm{~s}$, then nuclei were pelleted at $7000 \times g$ in microfuge for $30 \mathrm{~s}$. Pellets were resuspended by flicking in Buffer $\mathrm{C}(10 \mathrm{mM}$ Hepes pH 7.9, 25\% glycerol, $1.5 \mathrm{mM} \mathrm{MgCl}_{2}, 420 \mathrm{mM} \mathrm{KCl}, 0.5 \mathrm{mM}$ PMSF, $0.2 \mathrm{mM}$ EDTA) and incubated for $20 \mathrm{~min}$ in ice. Supernatants were collected after centrifugation for $2 \mathrm{~min}$ at $7000 \times \mathrm{g}$ in microfuge at $4^{\circ} \mathrm{C}$. Ten $\mu \mathrm{g}$ of 
nuclear extracts were incubated with 15000 c.p.m. of $\left.{ }^{32} \mathrm{P}\right]$-labelled oligonucleotide for $20 \mathrm{~min}$ in binding buffer (20 mM Hepes $\mathrm{pH} 7.5$, $10 \%$ glycerol, $55 \mathrm{mM} \mathrm{NaCl}, 20 \mathrm{mM} \mathrm{KCl}, 1 \mathrm{mM}$ DTT, $1 \mathrm{mM}$ EDTA, 2\% Ficoll-400, $0.2 \%$ NP-40) containing $2 \mu \mathrm{g}$ of poly(dl-dC) (Sigma) in a final volume of $20 \mu \mathrm{l}$. The free and protein-bound oligonucleotides were separated on a $4 \%$ polyacrylamide gel containing $2 \%$ glycerol, in $0.25 \%$ TBE at $150 \mathrm{~V}$ with refrigeration. The gel was dried and exposed overnight to a Kodak X-OMAT S film. Results were quantified using a Bio-Rad Imaging Densitomer GS-670. A double strand synthetic oligonucleotide reproducing the GATA site present in the globin gene (5' CACTTGATAACAGAAAGTGATAACTCT 3', Santa Cruz), was labelled with $\left[\gamma^{32} \mathrm{P}\right]-\mathrm{ATP}$ using T4 polynucleotide kinase (Promega) and purified through a BioGel Spin 6 column (Bio-Rad).

\section{Transfections}

The pLXSN retroviral vector was digested with EcoRI. The 2.2-kb p85 cDNA was isolated by gel purification and was inserted into the unique EcoRl site.

The recombinant pLXSN/p85AS DNA was transfected into the amphotrophic packaging cell line PT67 with the calciumphosphate coprecipitation technique. ${ }^{26}$ Transfected cells were selected in medium containing the neomycin analogue G418 (Calbiochem) at a concentration of $500 \mu \mathrm{g} / \mathrm{ml}$. The G418-resistant colonies were expanded and tested for virus production. Surnatant viral titers were determined by infection of NIH3T3 cells with serial dilutions of viral supernatants and scoring of G418-resistant colonies. A titre of approximately $1 \times 10^{6}$ colony-forming units $/ \mathrm{ml}$ of virus was generated. For transient viral infection, cells were incubated with a 1:1 mixture of virus-containing media from PT67 cells in the presence of polybrene $(4 \mu \mathrm{g} / \mathrm{ml})$ for $48 \mathrm{~h}$ prior to induction of differentiation with $2 \%$ DMSO or 5 mM HMBA.

\section{RNA extraction and Northern blotting}

Total RNA was extracted using the RNeasy mini kit (Qiagen). Ten $\mu \mathrm{g}$ of total RNA were denatured with formaldehyde and formamide for $15 \mathrm{~min}$ at $65^{\circ} \mathrm{C}$ and separated on a $1 \%$ agarose gel in MOPS buffer, pH 7 (20 mM Mops, 5 mM sodium acetate, $1 \mathrm{mM}$ EDTA). RNA was transferred to positively charged nylon membrane (Boehringer) and hybridized as described. ${ }^{23}$

\section{Acknowledgements}

This work was supported by I.O.R. Ricerca Corrente, by 'Funds for selected topics' from the University of Bologna, by CNR grants (PFIG, PFACRO and PF Target Project on Biotechnology), by the Ministero della Ricerca Scientifica (40 and 60\%). We thank Luca Cattini for flow cytometric analysis.

\section{References}

1. Marks PA, Richon VM, Kiyokawa H and Rifkind RA (1994) Inducing differentiation of transformed cells with hybrid polar compounds: a cell cycledependent process. Proc. Natl. Acad. Sci. USA 91: 10251-10254

2. Kiyokawa H, Richon VM, Venta-Perez G, Rifkind RA and Marks PA (1993) Hexamethylenebisacetamide-induced erythroleukemia cells differentiation involves modulation of events required for cell cycle progression through G1. Proc. Natl. Acad. Sci. USA 90: 6746-6750

3. Fibach E, Reuben RC, Rifkind RA and Marks PA (1977) Effect of hexamethylene bisacetamide on the commitment to differentiation of murine erythroleukemia cells. Cancer Res. 37: 440-444
4. Toker A, and Cantley LC (1997) Signalling through the lipid products of phosphoinositide-3-OH kinase. Nature 378: 673-676

5. Fruman DA, Meyers RE and Cantley LC (1998) Phosphoinositide kinases. Annu. Rev. Biochem. 67: 481-507

6. Ui M, Okada T, Hazaki K and Hazaki O (1995) Wortmannin as a unique probe for an intracellular signalling protein, phosphoinositide 3-kinase. Trends Biochem. Sci. 20: 303-307

7. Kimura K, Hattori S, Kabuyama Y, Shizawa Y, Takayanagi J, Nakamura S, Toki S, Matsuda Y, Onodera K and Fukui Y (1994) Neurite outgrowth of PC12 cells is suppressed by wortmannin, a specific inhibitor of Phosphatidylinositol 3-kinase. J. Biol. Chem. 269: 18961-18967

8. Jiang BH, Zheng JZ and Vogt PK (1998) An essential role of phosphatidylinositol 3-kinase in myogenic differentiation. Proc. Natl. Acad. Sci. USA 95: 14179 14183.

9. Kaliman P, Vinals F, Testar X, Palacìn M and Zorzano A (1996) Phosphatidylinositol 3-kinase inhibitors block differentiation of skeletal muscle cells. J. Biol. Chem. 271: 19146-19151

10. Bertagnolo V, Neri LM, Marchisio M, Mischiati C and Capitani S (1999) Phosphoinositide 3-kinase activity is essential for all-trans-retinoic acid-induced granulocytic differentiation of HL-60 cells. Cancer Res. 59: 542-546

11. Orkin SH (1995) Hematopoiesis: how does it happen? Curr. Opin. Cell. Biol. 7: $870-877$

12. Crossley M and Orkin SH (1994) Phosphorylation of the erythroid transcription factor GATA-1. J. Biol. Chem. 269: 16589-16596

13. Downward $\mathrm{J}$ (1998) Mechanisms and consequences of activation of protein kinase B/Akt. Curr. Opin. Cell. Biol. 10: 262-267

14. Duronio V, Scheid MP and Ettinger S (1998) Downstream signalling events regulated by phosphostidylinositol 3-kinase activity. Cell Signal 10: $233-239$

15. Kiyokawa H, Richon VM, Rifkind RA and Marks PA (1994) Suppression of cyclindependent kinase 4 during induced differentiation of erythroleukemia cells. Mol. Cell. Biol. 14: 7195-7203

16. Richon VM, Webb Y, Merger R, Sheppard T, Jursic B, Ngo L, Civoli F, Breslow R, Rifkind RA and Marks PA (1996) Second generation hybrid polar compounds are potent inducers of transformed cell differentiation. Proc. Natl. Acad. Sci. USA 93: 5705-5708

17. Klippel A, Escobedo MA, Wachowicz MS, Apell G, Brown TW, Gieldin MA, Kavanaugh WM and Williams LT (1998) Activation of Phosphatydilinositol 3-kinase is sufficient for cell cycle entry and promotes cellular changes characteristic of oncogenic transformation. Mol. Cell. Biol. 18: 56995711

18. Muise-Helmericks RC, Leighton Grimes H, Bellacosa A, Malstrom SE, Tsichlis $\mathrm{PN}$ and Rosen N (1998) Cyclin D expression is controlled post-transcriptionally via a phosphatidylinositol3-kinase/AKT-dependent pathway. J.Biol. Chem. 273: 29864-29872

19. Takuwa N, Fukui $Y$ and Takuwa $Y$ (1999) Cyclin D1 expression mediated

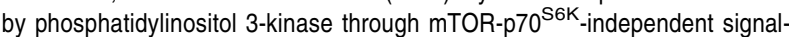
ing in growth factor-stimulated NIH3T3 fibroblasts. Mol. Cell. Biol. 19: $1346-$ 1358

20. Richon VM and Venta-Perez G (1996) Changes in E2F DNA-binding activity during induced erythroid differentiation. Cell. Growth Differ. 7: 31-42

21. Jackowski S (1996) Cell cycle regulation of membrane phospholipid metabolism. J. Biol. Chem. 271: 20219-20222

22. Sun B, Murray N R and Fields AP (1997) A role for nuclear phosphatidylinositolspecific phospholipase $\mathrm{C}$ in the G2/M phase transition. J. Biol. Chem. 272 26313-26317

23. Matteucci A, Faenza I, Gilmour RS, Manzoli L, Billi AM, Peruzzi D, Bavelloni A, Rhee SG and Cocco L (1998) Nuclear but not cytoplasmic phospholipase C $\beta 1$ inhibits differentiation of erythroleukaemia cells. Cancer Res. 58: 5057-5060

24. Roche S, KoegI Mand Courtneidge SA (1994) The phosphatidylinositol3-kinase $\alpha$ is required for DNA synthesis induced by some, but not all, growth factors. Proc. Natl. Acad. Sci. USA 91: 9185-9189

25. Marmiroli S, Bavelloni A, Faenza I, Sirri A, Ognibene A, Cenni V, Tsukada J, Koyama Y, Ruzzene M, Ferri A, Auron P, Toker A and Maraldi N M (1998) PI 3 kinase is recruited to a specific site in the activated IL-1 receptor I. FEBS Lett. 438: $49-54$

26. AusebelFM, BrentR, Kingston RE, More DD, Seidman GJ, Smith JA and StruhlK (1994) In: Current Protocols in Molecular Biology (Greene Publishing Associates/Wiley \& Sons) New York 